\title{
Easy to Manage When Recognized: Case Report of Cutaneous Larva Migranss
}

\author{
Dunja M. Vesković1,4, Dejan M. Ogorelica ${ }^{1,4}$, Siniša Đ. Sević3,4, \\ Aleksandra M. Fejsa Levakov ${ }^{2,4}$, Branislava M. Gajićn ${ }^{1,4}$, Tatjana N. Roš1,4 \\ ${ }^{1}$ Clinic of Dermatovenereology Diseases, Clinical Center of Vojvodina, Novi Sad, Serbia \\ ${ }^{2}$ Pathology and Histology Center, Clinical Center of Vojvodina, Novi Sad, Serbia \\ ${ }^{3}$ Clinic of Infectious Diseases, Clinical Center of Vojvodina, Novi Sad, Serbia \\ ${ }^{4}$ Faculty of Medicine, University of Novi Sad, Novi Sad, Serbia
}

\section{SUMMARY}

Introduction: Cutaneous larva migrans (CLM) is a syndrome, defined by clinical appearance of slowly migrating cutaneous eruption caused by inoculation with animal hookworms larvae in the skin. Despite the typical clinical presentation, CLM is frequently misdiagnosed due to its rarity in temperate climate urban communities.

Case Report: We report a case of a 42-year old female, admitted to an outpatient clinic with eruption of multiple intense pruritic, erythematous, exudative papules and oval plaques, located predominately on the back. The patient claimed that skin lesions started three weeks before the examination, during her vacation in Thailand, and at first, was taught to be caused by a contact with jelly fish. Lesions were treated unsuccessfully with oral antihistamines and various topical corticosteroids, which lead to more questions regarding the differential diagnosis. Dermoscopical and histopathological findings were indicative of parasitic infection, most likely CLM. A three-day course of oral albendazole, 400 $\mathrm{mg}$ daily, resulted in complete cure of the disease.

Conclusions: Careful clinical examination and detailed history taken from the patient are fundamentals for creating a set of differential diagnoses, that can be further clarified by the use of laboratory findings, imaging methods (including dermoscopy) and biopsy with histopathology. Although CLM has a benign self-limiting course, intense itch may substantially impact the quality of life, and possible visceral involvement or concomitant parasitic infection may lead to serious health deterioration in unrecognized cases.

Keywords: Larva Migrans, Skin Diseases, Parasitic, Hookworm Infections, Serpentine skin lesions, Dermoscopy

\section{INTRODUCTION}

Cutaneous larva migrans (CLM) is a syndrome, defined by clinical appearance of erythematous, serpiginous, pruritic and slowly migrating cutaneous eruption caused by animal hookworms larvae. Humans are accidental hosts, and infection takes place after contact with soil or sand contaminated by feces from infected animals, most often in tropical and subtropical regions. Despite the typical clinical presentation, CLM is frequently misdiagnosed due to its rarity in temperate climate urban communities $[1,2]$. The patient gave written consent for the anonymous publication of the case report. 


\section{CASE REPORT}

We report a case of a 42 -year old female, admitted to an outpatient clinic with eruption of multiple, intense pruritic, erythematous, exudative papules and oval plaques, located predominately on the back (Figure 1.). The patient claimed that skin lesions started three weeks before the examination, during her vacation in Thailand, convinced that the lesions were caused by a contact with jelly fish. Treatment with oral antihistamines and various topical corticosteroids was unsuccessful, which lead to more questions regarding the differential diagnosis. Soon after presenting at our Clinic and ceasing the use of previous therapy, the lesions started to become more elongated and progressed into typical curved linear plaques, indicating that this condition could be CLM (Figure 2.). Laboratory blood and urine findings were within normal range, abdominal ultrasonography and chest radiography showed no abnormalities either. After being additionally asked about her activities in Thailand, she disclosed that she frequently used no towels while lying in the sand of cats and dogs friendly beaches. Dermoscopy findings of the lesions showed homogeneous erythema, tiny vesicular structures, serous crusts and delicate scaling (Figure 3.). Biopsy specimens of the lesions revealed epidermal spongiosis and dermal mixed inflammatory infil- trate consisting predominantly of eosinophils, all characteristic findings in CLM (Figure 4.). A three-day course of oral albendazole, $400 \mathrm{mg}$ daily, resulted in complete cure of the disease.

\section{DISCUSSION}

Various hookworm species are responsible for causing CLM, most often Ancylostoma braziliense, Ancylostoma caninum and Uncinaria stenocephala $[3,4]$. CLM cases are frequent in regions with favorable climate and socio-economic conditions, such as regions of Central and South America, Africa and South-East Asia [1,5]. In high-income countries CLM is usually reported in tourists visiting endemic regions, but there are sporadic cases of autochthonous hookworm-related CLM acquired in temperate climate European countries such as Germany, France, UK, Serbia [2,6,7]. There is an estimation that the number of autochthonous CLM cases in high-income countries may increase during the next decades due to global warming [1].

Hookworms causing CLM need their natural hosts, usually dogs, cats, and wild animals, to complete the life cycle: larvae travel from the animal skin, through the bloodstream or lymphatic system to the lungs, ascend to the trachea, and coughed and swallowed they

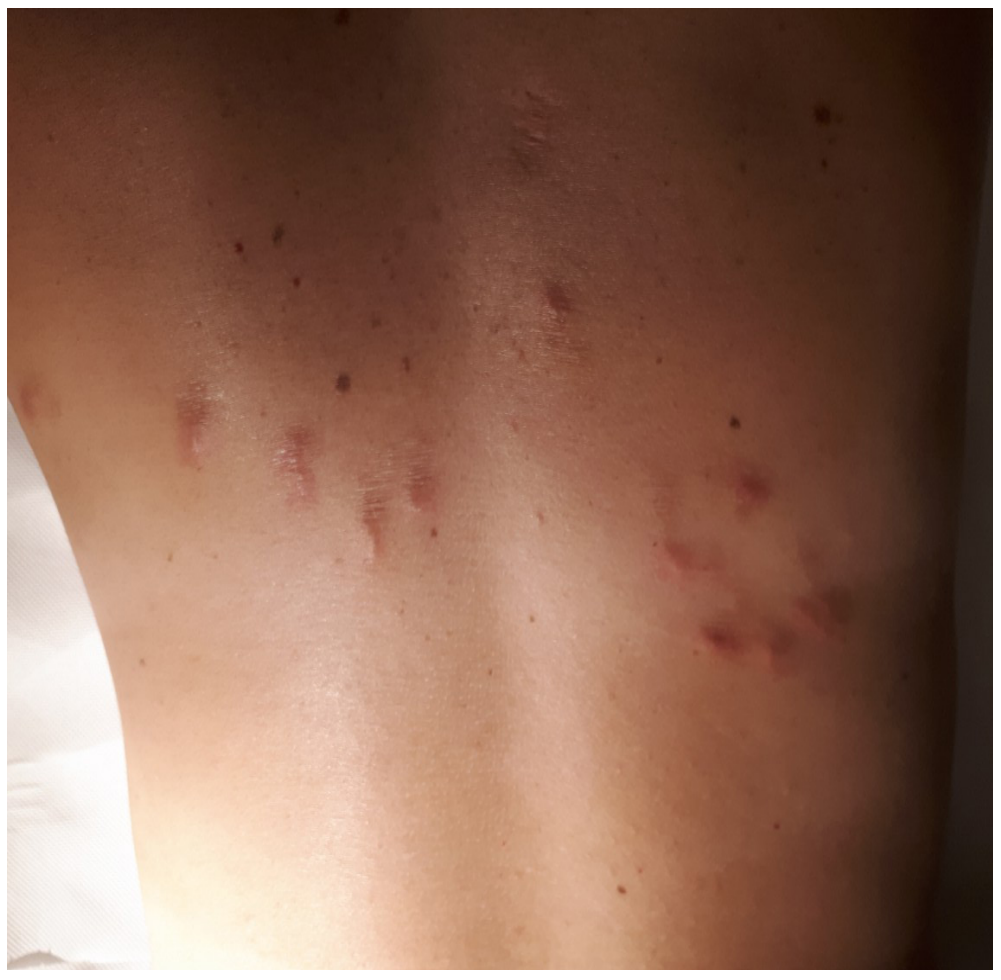

Figure 1. Clinical presentation at the first visit, before ceasing the oral antihistaminics and topical corticosteroid cream: multiple exudative erythematous lesionson the posterior side of the trunk 
Figure 2. Evolution of the lesions into serpigionous tracks 6 days later, at the second visit, after ceasing the both oral antihistamines and topical corticosteroid treatment

Figure 3. Dermoscopical findings of one of the lesions: exudative inflammatory disease with pale erythema, tiny vesicular structures, serous crusts and delicate scaling

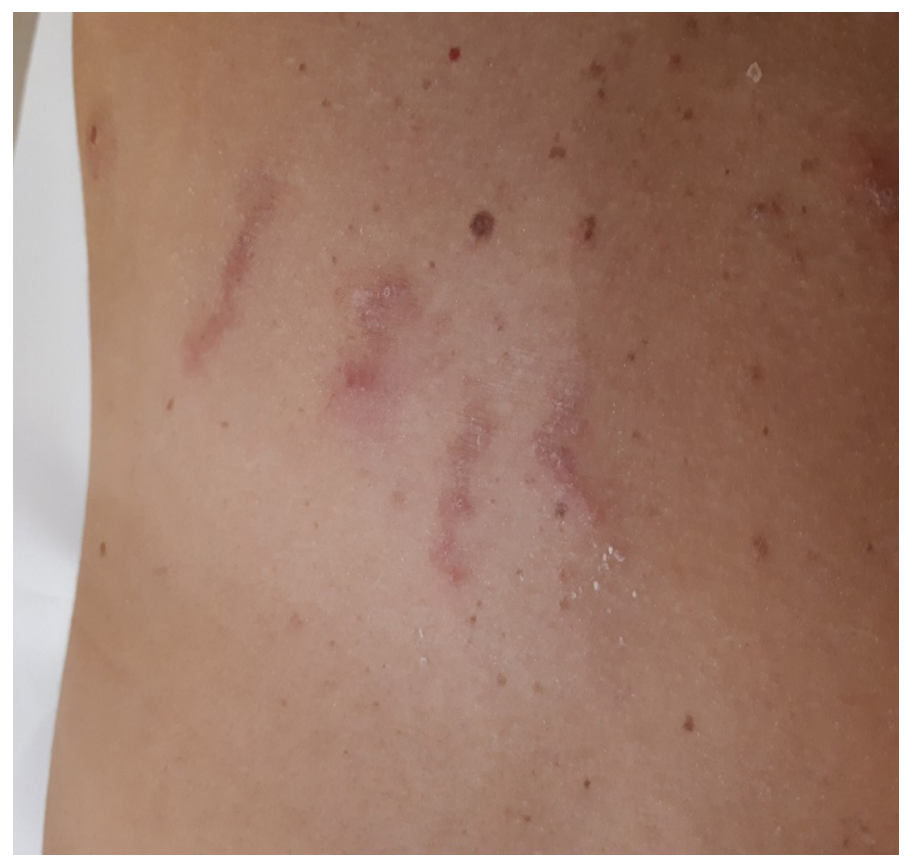

reach the intestines. In the intestines the larvae become sexually mature worms, capable of releasing their eggs in the feces. Under favorable environmental conditions such as temperature and humidity, eggs of parasites hatch and mature into infectious larvae producing proteinases that are enabling them to penetrate the intact skin and infect a new host $[7,8]$.

In humans, however, larvae can penetrate the skin but remain trapped in the outer layers since the enzymes they produce are insufficient for the deeper dermal penetration [9].

These enzymes are causing a cutaneous inflammatory reaction in a form of itch and skin lesions tracking larval migration.

The primary CLM lesion is non pruritic, reddish papule that appears at the pen- etration site, in both immunologically naive and in previously sensitized individuals [1]. The main complain that affects the patients is an intense itching, that usually starts 1015 days after larval penetration. As larvae wander along a serpiginous route at a speed rate of $2 \mathrm{~mm}$ to $2 \mathrm{~cm}$ per day, depending on a hookworm species, skin lesions usually develop into erythematous, elevated, serpiginous tracks $[2,9]$.

The skin lesions are commonly found in parts of body which are directly exposed to contaminated soil such as feet, hands and buttocks. Less common, lesion localization includes trunk, breasts, chest, the penile shaft and [5] the scalp [10]. CLM cases due to contact with contaminated clothes and towels[5], and extensive skin involvement have also been

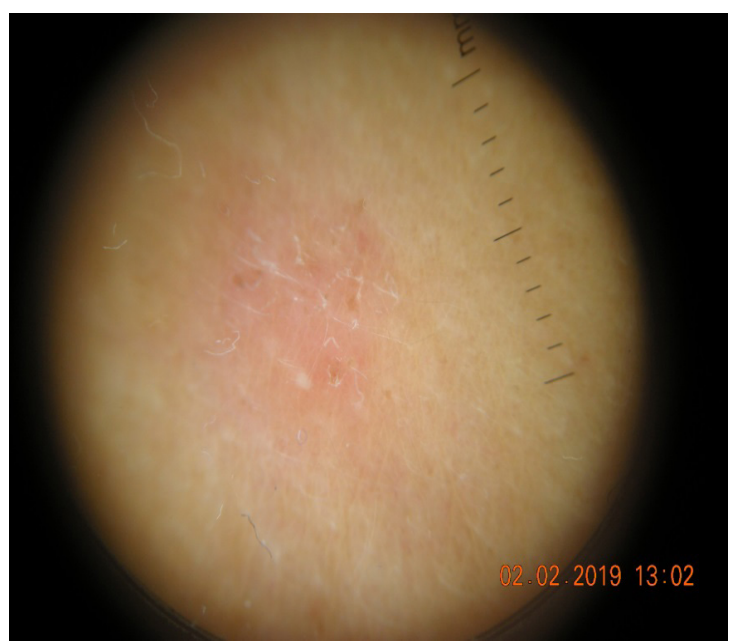




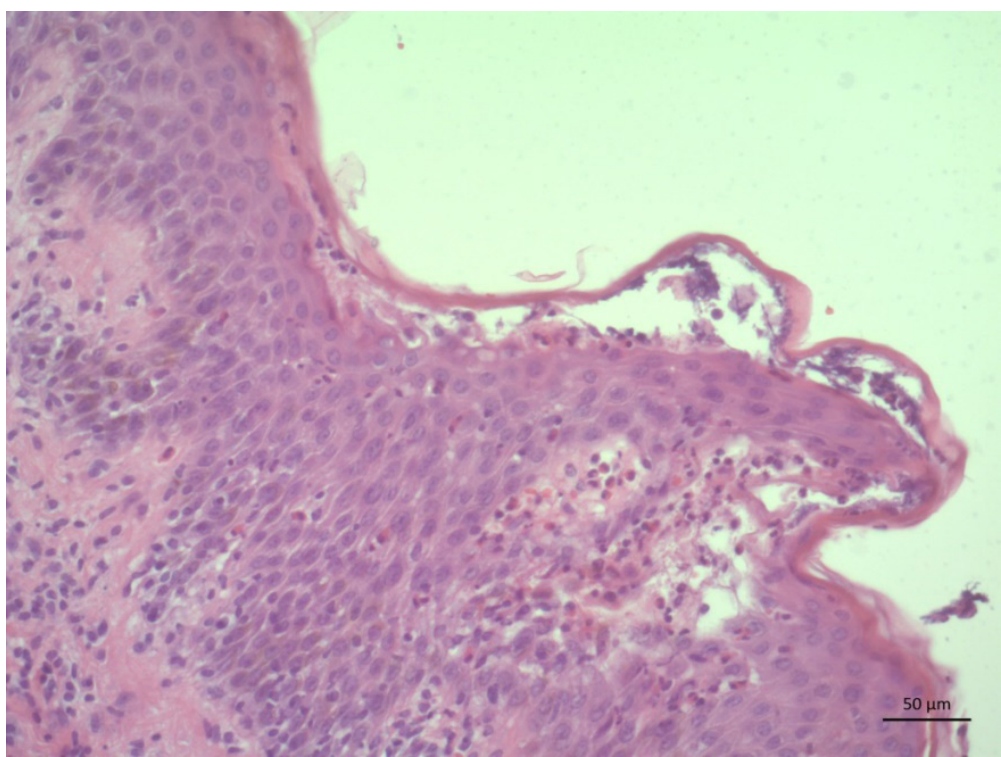

Figure 4. Histopathologyof the lesions revealed spongiosis and mixed inflammatory infiltrate containing mostly of eosinophils

described, sometimes leading to misdiagnosis $[11,6]$.

Laboratory findings are often of no diagnostic relevance in CLM and transient eosinophilia can only be suggestive of parasitic infection [1]. The complications of cutaneous larva migrans include secondary bacterial infection usually caused by scratching, local or general allergic reactions, Loeffler syndrome and rarely migration to internal organs [9]. A hookworm folliculitis is an uncommon CLM clinical form, marked by pustular folliculitis predominantly located on the buttocks of the patient [12].

Although the diagnosis of CLM is usually clinical, initial lesions without typical serpiginous morphology should be distinguished from common urticarial rash, urticarial vasculitis and eczema, where dermoscopy as a non-invasive method can be of some help. The dermoscopic features of eczema are dotted vessels usually distributed in clusters, yellow scales and serous crusting, while common urticarial rash and vasculitis frequently show a homogeneous erythematous back $\neg$ ground (avascular areas), sometimes with fine reticular/ linear vessels more frequent in common urticaria, and purple-red dots/globules on an orange-brown background are highly indicative of urticarial vasculi $\neg$ tis [13]. Despite a few reports of success [14], the efficacy of dermoscopy in detecting CLM has been questionable since the visualization of the larva is usually impossible with $10 \mathrm{x}$ magnification dermoscopes [15].

Ramondetta et al. [8] used fluores- cence-advanced videodermatoscopy to identify the precise position of suspected larva for the biopsy specimen, since skin lesions are due to inflammatory response and not where the actual position of the larva is. Larvae are ahead of the clinical tracts in an unpredictable chaotic migration, so in order to identify their possible position applying a flight theory was suggested [8].

In our case, dermoscopy findings showed overlap with some dermoscopic features of eczema and common urticaria, in favor of exudative inflammatory skin disease, represented with homogeneous erythema, few tiny vesicular structures, serous crusts and delicate scaling and were in concordance with obtained histopathologic findings.

Skin biopsy specimens of CLM usually show spongiotic dermatitis with spongiotic vesicles containing neutrophils and eosinophils and a mixed-cell dermal infiltrate with numerous eosinophils, but the larvae can rarely be found. In skin specimens, larvae are visualized as rounded bodies with an outer pink cuticle and central purplish structures that represent the intestine, but identification of the hookworm species is not possible in the tissue sections [16].

The disease is self-limiting, resolving in 2-8 weeks spontaneously, but the treatment is advisable because of intensive pruritus and high risk of secondary bacterial infection $[12,9]$. Symptomatic therapy for pruritus includes orally administrated antihistamines. Depending on the number of skin lesions and their localization, the treatment can be topi- 
cal or systemic [12]. The most frequently used drugs, and drugs of choice, are orally administrated ivermectin, given as a single dose of 200 $\mathrm{ug} / \mathrm{kg}$ and orally administrated albendazole, given in three daily doses of $400 \mathrm{mg}$ [7]. Ivermectin is highly effective and well tolerated in adults, but contraindicated in children younger than 5 years, or that weight less than $15 \mathrm{~kg}$ [1]. If there are few lesions, the thiabendazole ointment or cream 10\%, 3 times daily for 5 to 10 days,can be used [17].

\section{CONCLUSION}

Rushing into conclusions, both diagnostic and therapeutic, is a serious problem in medical practice. Careful clinical examination and detailed history taken from the patient are essential for creating a set of differential diagnoses, that can be further clarified by the use of laboratory findings, imaging methods (including dermoscopy) and biopsy with histopathology. Although CLM has a benign selflimiting course, intense itch and secondary infection may substantially impair the quality of life, while possible visceral involvement or concomitant parasitic infection may lead to serious health deterioration in unrecognized cases.

\section{CONFLICTS OF INTEREST}

All authors declare no conflict of interest.

\section{REFERENCES}

1. Heukelbach J, Feldmeier H. Epidemiological and clinical characteristics of hookworm-related cutaneous larva migrans. Lancet Infect Dis 2008;8(5):302-9.

2. Hochedez P, Caumes E. Hookworm-related cutaneous larva migrans. J Travel Med 2007;14(5): 32633.

3. Tekely E, Szostakiewicz B, Wawrzycki B, KądzielaWypyska G, Juszkiewicz-Borowiec M, Pietrzak A, et al. Cutaneous larva migrans syndrome: a case report. Postep Derm Alergol. 2013;30(2):119-21.

4. Sunderkötter C, von Stebut E, Schöfer H, Mempel $M$, Reinel $D$, Wolf $G$, et al. $S 1$ guideline diagnosis and therapy of cutaneous larva migrans (creeping disease). J Dtsch Dermatol Ges. 2014;12(1):86-91.

5. Tianyi FL, Agbor VN, Kadia BM, Dimala CA. An unusual case of extensive truncal cutaneous larva migrans in a Cameroonian baby: a case report. Journal of Medical Case Reports 2018;12:270.
6 .Tomovic M, Skiljevic D, Zivanovic D, Tanasilovic $S$, Vesic S, Djakovic Z, et al. Two cases of probable endogenous extensive cutaneous larva migrans in Serbia. Acta Dermatovenerol Alp Pannonica Adriat. 2008;17(1):37-40.

7. Perić J, Lekić B, Reljić V, Ćirković L, Škiljević D. Cutaneous Larva Migrans - Report of 2 new Cases Locally Acquired in Serbia. Serb J Dermatol Venereol 2017;9 (4):149-53.

8. Ramondetta A, Ribero S, Quaglino P, Broganelli P. In Vivo Observation of Cutaneous Larva Migrans by Fluorescence-Advanced Videodermatoscopy. Emerg Infect Dis. 2021;27(1):281-3.

9. Schaub NA, Perruchoud AP, Buechner SA. Cutaneous larva migrans associated with Löffler's syndrome. Dermatology 2002;205(2):207-9.

10. Meotti CD, Plates G, Nogueira LLC, Silva RA, Paolini KS, Nunes EM, Bernardes Filho F. Cutaneous larva migrans on the scalp: unusual presentation in a typical clinical presentation. An Bras Dermatol 2014;89(2):332-3.

11. French SJ, Lindo JF. Severe Cutaneous Larva Migrans in a Traveler to Jamaica, West Indies. J Travel Med 2003;10(4):249-50.

12. Caumes E, Ly F, Bricaire F. Cutaneous larva migrans with folliculitis: report of seven cases and review of the literature. $\mathrm{Br} \mathrm{J}$ Dermatol 2002;146(2):314-6.

13. Errichetti, E., 2019. Dermoscopy of inflammatory dermatoses (inflammoscopy): an up-to-date overview. Dermatology practical \& conceptual, 9(3), p.169.

14. Veraldi S, Schianchi R, Carrera C. Epiluminescence microscopy in cutaneous larva migrans. Act Derm Venereol 2000;80:233.

15. Zalaudek I, Giacomel J, Cabo H, Di Stefani A. Entodermoscopy: A new tool for diagnosing skin infections and infestations. Dermatology 2008;216:14-23.

16. Balfour E, Zalka A, Lazova R. Cutaneous larva migrans with parts of the larva in the epidermis. Cutis (New York) 2002;69(5):368-70.

17. Blackwell V, Vega-Lopez F. Cutaneous larva migrans: clinical features and management of 44 cases presenting in the returning traveller. British Journal of Dermatology 2001;145: 434-7. 


\title{
Lako rešivo kada se prepozna: Prikaz slučaja - kutana larva migransa
}

\author{
Dunja M. Vesković ${ }^{1,4}$, Dejan M. Ogorelica ${ }^{1,4}$, Siniša Đ. Sevićc ${ }^{3,4}$, \\ Aleksandra M. Fejsa Levakov ${ }^{2,4}$, Branislava M. Gajić, ${ }^{1,4}$, Tatjana N. Roš ${ }^{1,4}$ \\ ${ }^{1}$ Klinika za kožno-venerične bolesti, Klinički centar Vojvodine, Novi Sad, Srbija \\ ${ }^{2}$ Centar za patologiju i histologiju, Klinički centar Vojvodine, Novi Sad, Srbija \\ ${ }^{3}$ Klinika za Infektivne bolesti, Klinički centar Vojvodine, Novi Sad, Srbija \\ ${ }^{4}$ Medicinski fakultet, Univerzitet u Novom Sadu, Novi Sad, Srbija
}

\section{KRATAK SADRŽAJ}

Uvod: Kutana larva migrans predstavlja sindrom, koji se u kliničkoj slici odlikuje pojavom sporo migrirajućih kožnih lezija, prouzrokovanih inokulacijom animalnih larvi, iz različitih familija rudarskih glista, pod kožu. lako ima relativno karakterističnu kliničku prezentaciju, postavljanje dijagnoze CLM često ne ide lako, pre svega zbog svoje veoma retke pojave u urbanim sredinama u umerenom klimatskom pojasu.

Prikaz slučaja: Naš prikaz slučaja prezentuje četrdeset dvogodišnju ženu, koja se zbog osećaja intenzivivnog svraba kao i brojnih promena na koži, javlja na ambulantni pregled. Promene koje su pre svega lokalizovane na leđim, u vidu eritematoznih, eksudativnih papula i ovalnih plakova su se prvi put pojavile pre tri nedelje, tokom njenog godišnjeg odmora na Tajlandu, za koje je bolesnica verovala da su nastale nakon kontakta sa meduzom. Lezije su, neuspešno, u početku tretirane topikalnim kortikosteroidima a za svrab su ordinirani oralni antihistaminici. Saznanja nakon dermoskopije i patohistološkog pregleda kože su govorili u prilog parazitarne infekcije, najverovatnije CLM. Trodnevna terapija sa oralnim preparatima albendazola, 400mg dnevno, dovela je do potpune rezolucije bolesti.

Zaključak: Pažljiv fizikalni pregled, kao i detaljna anamneza su osnova za lakše razumevanje promena te bolju selekciju diferencijalnih dijagnoza a svakako ih prate i pomažu im laboratorijski nalazi i invazivne i neinvazivne metode vizuelizacije poput dermoskopije, biopsije i patohistološke analize. lako CLM predstavlja benigu samoograničavajuću bolest, intezivan svrab je ono što značajno narušava kvalitet života, a osim toga potencijalna udruženost sa drugim parazitarnim bolestima ili alergijskom senzibilizacijom je ono što može u većoj meri da ugrozi zdravlje bolesnika.

Ključne reči: larva migrans, kožne parazitske bolesti, infekcije rudarskom glistom, zmijolike kožne promene, dermoskopija 